Portland State University

PDXScholar

1975

\title{
Counseling Needs of Mastectomy Patients: Reach to Recovery Program
}

\author{
Elaine Lowe \\ Portland State University
}

Follow this and additional works at: https://pdxscholar.library.pdx.edu/open_access_etds

Part of the Rehabilitation and Therapy Commons

Let us know how access to this document benefits you.

\section{Recommended Citation}

Lowe, Elaine, "Counseling Needs of Mastectomy Patients: Reach to Recovery Program" (1975).

Dissertations and Theses. Paper 2077.

https://doi.org/10.15760/etd.2076

This Thesis is brought to you for free and open access. It has been accepted for inclusion in Dissertations and Theses by an authorized administrator of PDXScholar. Please contact us if we can make this document more accessible: pdxscholar@pdx.edu. 
4.

COUNSELING NERDS OF MABRECTOAY PATIENTS:

REACH 20 RECOVERY PROGRAM.

$3 y$

.

ELAINE LONE:

A practicum submitted in partial fulfillment

of the requirements for the degree of

MASTER OF SOCIAL. WORK

PORTLAND STATE UNIVERSITY

Approved by

Department

1975

Date

Dues 22,1925 
INTRODUCTION AND ACKNOWLEDGEMEIVTS

CHAPTER

I. REVIEW OF LITERATURE.

I BREAST CANCER IN THE UNITED STATES

$i$

II COUNSEI-ING NEEDS OF THE MASTECTONY PATIENT.

III SOHE COUNSEIITG AFYROACHES

IV REACH TO RECOVERY PROGPAM

A. Background

B. Oregon, Chapter

II DESIGN OF STUDY

I METHOD OF INDUIRY

II TARGET POPULATION

III QUESTIONNAIRE DESCRIPIION

IV LIMITATIONS OF STUDY

A. Review of Literature.

B. Target Population

C. Most Fecent Mostectomy Three Years $A g O$

24

24

26

27

28

28

28

28 
III. RESULTS OF QUESTIOMTAIRE.

II INTERVIEW WITH MRS. NORA JANIK.

IV CONCLUSIONS AND RECOMMENDATIONS '

I BACKGROUND AND CHARACTERISTICS OF THE VOLUNTEER

II COUNSEIING EXPERIENCES AND PEPSONAL FEELINGS

III COUNSELING SERVICES.

IV INDICATION FAOR FURTHER STUDY

ALPENDIX A. DEFINITION OF TYERMS 
The following is a descriptive and exploratory study of the counseling needs of mastectomy patients and how they are met, and of the Reach to Recovery program through the American Cancer Society as a way of meeting these needs.

:The writer has surveyed the professional Iiterature and, briefiy, some popular literature on the subject.. In addition, a questionnaire was addressed to a group of. Portland Reach to Recovery volunteers who served as a target population, one of whom. was interviewed more fully."

I would like to acknowledge with thanks the most $h \in I p f u l$ cooperation of Mrs. Nancy Brice, Service Director; American Gancer Society, Orecon Division and Mris. Nora Janik, State Coordinatop, Reach to Recovery, American Cancer, Scciety, Oregon Division, without whön the "study could not have been done. My thanks, too, to Mrs. Ada Portland state for her continuing guidance and assistance and to Dr. Frank Miles for his assistance in designing the questionnaire and to my husband and family who not only helped but bore with me. 
IIST OF TSPIES

DATA FOR THE AHAIYSIS OF CHARACTERISTICS OF VOLUNTEERS

PERCENTAGE OF VOLUNTEERS HAVING SURGERY' FROM ZERO TO 20 "YEARS.

PERCENTAGE OF TIYES SIGNIFICANT FERSONS

INDIC ATED AS BEING MOST HELPFUL

EMOTIONALIY BEFORE AND' IMISEDIATELY AFTER MASTECTOMY.

IV PERCENTAE OF PIMES SIGNIFICANT PERSONS

INDICATED AS DOING COUNSELING BEFORE AND

IMMEDIATELY AFIER MASTECTOMY

34.

DATA RELATIYG TO SOME ISSUES SURROUNDING

BREAST CANCER AND MASTECTONIES AND THEIR

RELATIVE SIGNIFICANCE. TO RESPONDENTS

REASONS GIVEN FOR JOINING REACH TO RECOVERY

TOPICS RELATING TO CONSUITEES' MASTECTOMIES MOST FRE WUENILY DISCUSSED WITH THEM BT

REACH TO RECOVERY VOUUNPEERS

VIII LENGTH OF TIKE VOLUNTEERS HAVE SERVED IN PROGRAM 
CHAPTER I

\section{REVIEW OF IJTERATURE}

\section{BREAST CANCER IN THE UNITED STATES}

Breast cancer is the leading cause of cancer death in. women in the United States. In I973, the estimated deaths from breast cancer in this country were 32,650 and, accórding to the American Cancer Society, nearly $7 \%$ of the American female population wili develop breast cancer.?

Research has shown that those women nost likely to develop breast, cancer are obese, 40-44; over 60 . who have never had children; somen who bore their first child over 30. Further characteristics are:

1. history of benign breast disease

2. daughters of parents with a familial history of cancer and whose female, blocd relatives have bad a history of breast cancer. 3

1 Justin J.Stein, M.D., "Hi-Risk Groups", Cancer News, Sprisg/Sunner, 1974, Vol. 28,; H], p.4.:

2 American Cancer Society, "in3 Cancer Eacts \& Figures", New York, 1973.

.3 Justin J. Stein, M.D., "Hi-Risk Groups", Cancer News, Spring/Summer, 1974, Vol, 28, \#1, p. 4 . 
Risk of cancer in the above group is $70-500 \%$ higher

than the average, depending on the combination of characteristics. The two age peaks are $40 \div 44$ and cver 50 , and aich of the educating activities regarding early detoction ave directed to women in the $40-44$ age range. 4

The process which a woman must, go through when a lump is discovered in her breast is to be hospitalized to have a breast biopsy to determine whether the lunp is nalignant or benign. In the majority of cases (60 to $80 \%$ ) the breast biopsy is benign. 5 For those women in whom the Iump has been discovered to be malignant, the method of treatment is.almost always a mastectomy or surgical removal of the breast. The operation is performed, .. if necessary, immediately upon discovering that the Iump is. malignant and within a short period of time after the biopsy itself. This means that when a woman goes into: surgery for a biopsy, she may have a bresst removed as well. The proceaure is explained to her ahead of time, but she doesn't know until the operation is over whether in addition to the biopsy, she has had a mastectomy as well.

4 . Ibid.

5 Margaret Owen, "Special Care for Patient, Who Has Breast Biopsy", Nursing Cinice of North America, June, 1972, Vol. 7, p. 373-82. 
The above method of treatment is usea extensively, and in the United States today, over 500,000 women are living who have had a mastectomy. 6 The 5-year survival rate of women who have had this operation is $80-85 \%, 7$ However, when the cancer has spread to the Iymph nodes outside the breast, the 5-year survivil is cut to $40-45 \% .8$

The operation itself often results, in addition to the removal of the breast, in difficulty in arm movement and use of the arm.

Ninety five percent of patients discover the condition themselves, but of this group 60\% have cancer which has already spread to the Iymph nodes outside the breast. 9 The Mmerican Cancer society directs its educaticnal efforts towaras early detection and encourages breast seIf-examination and regular physical examination. There is literature printed indicating whet to look for in seif-examination and films on the subject as well which some gynecologists show to their patients for educational purposes.

6 John L. Sawyers, M.D., "Reach to Recovery - A Post Mastectomy Rehabilitative Program", Journal Tennessee Vedical

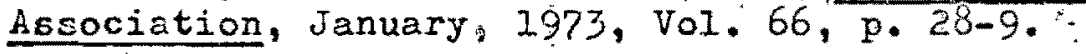

7 American Cancer Society, "'73 Cancer Facts \& Figures", New York, 1973.

8. Ibid.

9. Ibid. 
Unfortunately, despite better treatment and means of detection, the mortality rate from breat cancer has not significantly decreased over the past 35 years 10 Because of this, in 1972, the American Cancer Society launched a nationwide attack on breast cancer. Since the chances of survival are so much greater when the malignancy has not spread to areas outside the breast, their thrust was to develop inethods to diagnose the cancer when it is in an early or pre-clinical stage -- so carly as to be $100 \%$ curable. More than $\$ 2,000,000$ was spent to help support 12 major detection centers as part of this effort. 11 One of these centers is at Good Samaritan Hospital in Portland. where there is a now emphasis on the use of mammography ( $x-x a y$, examination) and thermography (heat sensitive photograph) to detect the cancer in its earliest and most curable stages.

10 Ibid. 11 Ibid. 
II COUNSELING NEEDS OF THE MASTECTOHY PATIENT

Historically, the interest of the medical profession has

been

in survival times of breast cancer patients and in assessing

medical success. More recently, there has been a growing concern among medical people about the quality of life of a mastectomy patient after the operation. As Dr. WiIIiam Markel pointed out at the Second National Conference on Cancer of the Breast, "If the patient cannot come to terms with her surgery, return to her fanily and get back to a fairly nornal life, there is a question of the validity of the survival tine."12

Much time at this conference was given to directing itself to the issue that the medical community had failed to provide. the necessary emotional support needed to help women confront and deal with the issues of fear of dying and/or recurrence of disease, the mutilation of her body and how she will be regarded by others close to her.. Although her general physical health following the operation may be good, the emotional and physical impact may be temporarily devastating. The womar who has had: a mastectomy must not only concern herself with her physical rehabilitation in obtaining and becoming accustomed to ari artificial breast and perhaps in regaining the use of her arm,

12 William. Markel, M.D., "Program for the Ronabilitation of the Breast Cancer Patient", Cancer, December, 1971, Voi. 28, p. 1676-78. 
but, in addition somehow resolve her own feelings. about a life threatening disease and the consequences of the mastectomy itself. Sne is facing a totally new situation where old coping methods will. not necessarily work.

Helen Harrell, now a Director of Education at Hermann Hospital School of Vocational Nursing in Houston, Texas, expressed her own thoughts in an article in the Aprid, 1972 Journal of Nursing. ${ }^{13}$ she had had a mastectomy and one of her many fears following the operation was that she was having a nervous breakdown. She had never been warned that crying jags would occur, but would also pass, that others had bad dreams, that the inner part of ner arm would be numb. She, said ahe became depressed and death oriented. Her own emotional reaction motivated her to reach out to help others and reinforced her idea that it is the quality and not the quantity of iife that counts.

Recently, in the popular literature, "there has been much attention given to some of the problems faced by women who have breast cancer and mastectomies. What once was a taboo subject and referred to as "rom's shame" has now become

13 Helen C. Harrell, "To Lose a Breast", American Jcurnal of Nursing, April, 1972, Vol. 72, p. 676-77. 
common and well publicized knowledge. 14 feelings.about their own surgeries and breast cancer in the press. In two recent articles in women's magazines, Marvella Bayh and Betty Ford related some of their own experiences and feelings regarding their breast surgery. 15 Mrs. Ford stated. that one of her reasons for granting an interview was that she hopedit would help other women to discuss their operation ireely. Both women looked upon the surgery as life saving and emphasized the importance of the support of those closest to them. They both offered an optimistic view in spite of the potentially fatal nature of breast cancer and said that life was móre meaningful for them now.

14 Marvella Bayh, "Betty, Happy and Me", Ladies Home Journal, January, 1975, Vol. 92, p. 63.

15 Ibid. Betty Foru, "I Feel Iike I've Been Reborn", McCall's February, 1975, Vol. 102:5, p. 98: 
III SOHE COUNSELING AFFROACHES

In reviewing the medical literature, it seemed apparent that there was an acknowledgment, at least in the past five or six years, that there is a need to offer emotional support and guidance to women who have mastectomies to offet some of the potientially damaging psychological consequences of the disease and the operation.

Roberta Klein, M.S.W., in presenting her paper at the ACS 19,72 Breast Cancer Conference, ${ }^{16}$ stated that general mental health concepts on how to handle crisis as outlined by Caplan and Iindeman, are applicable to breast cancer patients. In her paper, she defined a crisis as "an insolvable problem precipi. tated by stressful or hazardous events which cause a loss of equilibrium for the individual". At this time, sine stated, previous coping methods don't work and the patient may tip toward or away from mental health. When considering a breast cancer patient, several characteristics are important:.

16. The crisis is time limited. It is better to take advantage in treatment of a short term disequilibrium rather than to try picking up the pieces months ox years later when an incapacitating problém presents itself.

16 Roberta Klein, "A "Crisis to Grow On", Cancer, December, 1971, Vol. 28, p. 1659-65. 
2! The crisis may call forth old feeljings and unresolved conflicts, a remembrance of another loss, and this may vary with the individual.

3: The individual must actively work on the problem rather than centering their activities on avoiding it in order to bring about a healthy resolution of the crisis.

4. The family members may help or hinder in how they do or do not allow the patient to express her feelings, in how much they are willing to give her extra Iove, in how sensitive they are in picking up cues to the patient's needs, or if they are in a crisis themselves they may find the problem too painful to face.

5. A certain amount of tension and anxiety is essential to motivate the individual toward resolving their crisis.

Ms. Klein sees the tasks to be performed by the patient as:

1. accepting the loss of the breast by being allowed to fully mourn as well as to feel and express the grief around the fear of the possible further loss of perhaps her husband or even her Iife;

2. re-integrating her self-image worthy of love and the rewards of life;

3. beginning to make peace with the idea cf a potential recurrence in five to ten years.

The patient who successfully accomplishes these tasks is using strengths she has probably never had to use before and in 
so doing becomes a different and stronger person.

In general, Ms. Klein further outlines ways the patient

can be helped to perform the above tasks.

1. Help her to express her feelings. These could be fear that no man could ever love her, that she is being punished for a sin, anger that this should happen to: her or grief at the loss of part of hex body. Permit her to express her grief, and help her master feelings that are unacceptable tó her.

2. Help her sort out real from unreal. What she imagines is much worse than actual facts. Knowledge of the facts will dissipate the imagined consequences.

3. Don't give false reassurances.

4. Help her to anticipate the future and think through what it will be like after the operation and what she will have to do. Help her to understand that depression is normal under the circuinstances. A woman's age may have much to do with her attitude as well as how much emphasis she places on physical appearance.

5. Help the family to understand the patient's feelings and to express theirs... In particular, it is important to help the husband express his feelings which if hidden may become a matter of concern to his wife. Both should be helpea to express their anxieties together. 
6. Help the patient to consider how and what to tell significant people about the mastectomy and breast cancer.

Ms. Klein states that who helpe nay be any one of several people" - the doctor, the family, the nurse or Reach to Recovery volunteer.

A's evidenced in the literature, there are some hospitals that already have an organized effort to help breast cancer. patients with the above concerns. Ms. Klein mentioned the Memorial Eospital in New York, where a team of M.D., physical therapist, nurse, social worker and Reach to Recovery volunteer meet daily with every patient still hospitalized. They teach the patient the necessary exercises for physical functioning, as well as about prostheses, and their proper care and offer an opportanity to air questions about cancer and their fears. The group of mastectomy patients.in itself is a great help and helps the patient cope with overwhelming feelings of the operation and disease.

Dr. Harry S. Goldsmith and Dr. Edgardo S. Alday in their description of the role of the surgeon in rehabilitating the breast cancer patient ${ }^{17}$ stated that dealing with psyciological probiens should begin prior to the operation. They pointed out that this is a good time to indicate, any favorable clinical

17 Harry S. Goldsmith, M.D., et al, "Role of the surgeon in Rehabilitation of Breast, Cancer Patient", Cancer, December, 1971, Vol. 28, p. 1672-75. 
aspects to the patient and to help her air her fears of the operation itself. It is also heIpful to have onother family nember present when discussing the various aspects of breast surgery since it may be helpiul later on in dealing with the patient's concerns. The authors stated that after the operation is usually a time when the patient experiences depression and that the sight of another woman such as a Reach to Recovery volunteer is particularly reassuring in addition to giving the patient an opportunity to help herself by starting exercises to prevent limitation of arm movement.

Beien Harrell, a member of Reach to Recovery ind a nurşe who is the Director of Education at Hermann Hospital School of Vocational Nursing in Houston, Texas, 18 feels that the best time to counsel and offer emotional support are the ten days while the patient is hospitalized and that intensive enotional and physical rehabilitation can be done with continuity at this time. It is a time when most family members are available and their questions can be answered. Through" careful teaching many of the patient's fears can be diminished. By receiving proper information she will be spared the results of half-truths and misinformation from well meaning friends that could otherwise be fear provoking. Hopefully, by the time the patient Ieaves the

18 Helen C. Harrell, "To Lose a Breast", American Journal of Nursing, April, 1972, Vol. 72, p. 676-77. 
hospital, and as a result of the counseling, she will be able, to cope with herself and other's reactions to her.

Margaret Owen, a clinical specialist in surgical nursing at Good Samaritan Hospital in Phoenix, Arizona writes of a program at this hospital to plan for the special care of the patient who has a breast biopsy. 19 she points out that even before the patient is hospitalized she has begun to cope with the idea of breast surgery and breast cancer and so the coping mechanisa which she has already developed must be recognized. The patient is admitted to Good Samaritan. Hospital on the afternoon prior to the operation and is approachine a crisis point: "She needs all her strengths to deal with it. The nurse who will be with her throughout the operation and afterwards is introduced to her. and carries back to the medical team her information and impressions regarding the patient to assist in planning for her. In the pre-operative period the patient is given information: regarding the surgery and what to"expect afterwards. The nurse either answers questions or respects the patieni's wishes not to talk about it. If the husband or other family member is there they may be included in the conversation. A permit must be signed by the patient prior to the mastectomy should"it be necessary. If the biopsy is malignant, the husband should be

19 Margaret Owen, "Specizl. Care for Patient Who has Breast Biopsy", Nursing Clinics of North America, June, 1972, Vol. 7, p. 373-82. 
told right away. The nurse sees the patient immediately when she wakes up and hopes to provide an atmosphere that is comfortable and relaxing which will allow the patient to ventilate her feelings. The exercises begin the following day and the Reach'to Recovery voluntée may visit then if the physician so desires. The patient is in the hospital about seven days and durins this time "has an opportunity to make a psychological adjustment, get information and receive any professional help. needed. The nurse plans a home visit two to four months after discharge.

Recently, the University of Texae Southwest Medical School recivied a $\$ 1,000,000$, three year contract "from the National Cancer Institute to fund a new program which will assemble teams of experts to provide rehabilitative services for cancer patiento. The purpose is to provide a model for similar projecte elsewhere and to counter "unwarranted pessimism among medical personnel regarding such patients' rehabilitation".

Services will include physicaz restoration programs, specialized nursing, prosthatic consultation, dietary counseling and counseline for the patients' families.

AlI of the above programs seem to take advantage of the

20 "After Cancer Effort Funded", Oregon Jounnal, February 3. I975, Portland Oregon, The Oregonian Pliblishing Company. 
theories of crisis intervention as outlined by Ms. Klein in attempting to deal with the patient's psychological problems immediately and to prevent further and more serious emotional problens from developing and to resolve the crisis and provide the tools for a healthy adjustment to a life threatening and mutilating illness. The issues of fear of, recurrence of disease, death, bodily mutilation and relationships with family and otherś can be dealt with in a supportive atmosphere where professional help is available. 


\section{REACH TO RECOVERY PROGRAM}

\section{A. Background}

'Reach to Recovery is the name given to a volunteer progran under the auspices of the American Cancer Society" which is designed to assist post-mastectomy patients. The volunteers themselves are all women who have had mastectomies.

Although there have been other women active in counseling post-mastectomy patients, it is Terese lasser who is most commoniy associated with starting the Reach to Recovery program as it is known now. Mrs. Lasser is a woman who had a mastectomy in 1952 in New York. She felt a need herself at that time for some kind of emotional support and physical rehabilitation which was lacking. According to her book "Reach to Recovery"? it was through her own personal experience by trial and error that she developed a basic philosophy which turned out to be a useful approach to the problems of a mastectomy patient. Her own experiences of wondering how active she could be, how the Ioss of a breast would affect her relationship with hex husband, and her feelings of depression and despair made it possible for her to understand the feelings of other women in the same situation.

21. Terese Lasker and William Ranall Clarke, Reach to Recovery, New York: Simon and Schuster, 1972. 
Because, she had no: one to guide her in specific exercises, she developẹd her own to regain the use of her arm. Another difficulty Mrs. Lasser encountered was finding a place to buy an artificial breast.

Perhaps because of her own personality ard background as a woman who had been very active as a mother and wife and involved in activities outside the home, it was a natural move for her to want to do something to develop some kind of a program to assist other post-mastectomy patients.

Mrs. Lasser tells of being asked by a friend to visit a mutual friend in the hospital after a mastectomy with the idea that her own efforts at recovery might be helpful to their friend who was extremely depressed. During the visit, all efforts to reach her seemed to fail until Mrs. Lasser told her that she herself had had a mastectomy: Her friend took such hope at this that Mrs. Lasser states, "At that precise moment, I think, the idea for Reach to Recovery was born." 22

She discussed with her own surgeon, her idea for Reach to Recovery and he approved, but cautioned her about the resistance she would probably find from the medical community. Fortunately, she had the tifie, the money and the will to finance and carry through her ideas. Her husband, J.. K. Lasser, was an author and 22 Ibid., 27 
publisher and published a manual written by his wife, wich was a "how-td" for other mastectomy patients. 23 As Mrs. Lassar states, "the program's core was my own experience in achieving maximuni mental and emotional recovery as well as physical health after having a preast removed. This is what enabled me to speair to other women in the same situation with understanding, hope and confidence". 24 Mrs. Lasser's surgeon was incleed correct in cautioning her about the resistance she would meet. Her activities were greeted with some suspicion by physicians who were skeptical of her because she was not a trained professional. However, after much personal effort, traveling across the country talking to individual women and to groups and training others to do the same", her program began to catch on and be accepted. The Reach to Recovery Program merged with the American Cancer Society in 1969. The society colld offer its own organization of 58 divisions, 3,000 units and more than 2,000,000 volunteers. Mrs. Lasser became a national consultant to Reach to Recovery, and her programibenefited from the medical supervision at a locaI level, which included physician, rimse, physiotherapist and

23 Terese Lasser, Reach to Recovery, A Manual for Women Who Have Had Breast Sursery, Revised Edition, 1969, New York.

24 Terese Iasser \& William Kendall Clarke, Reach to Recovery New York: Simon and Schuster; 1972. 
trained Reach to Recovery volunteer. 25

Some interesting statistics are reported by William Markel, M.D., Vice Fresident for Service and Rehabilitation, American Cancer society. 26 In 1969-70, the first year the program was part of American Cancer Society, 1,825 volunteers visited andassisted 7,671 women in 952 hospitals, with 2,907 physicians requesting this service for their patients. In 1970-71, there was a dramatic increase; 3,355 volunteers visited and assisted 17,481 patients in 1,571 hospitals. The number of physicians requesting their service vas" 5,694 .

\section{B. Oregon Chapter}

In Oregon, according to Mrs: Nora Janik, State Coordinator for Reach to Recovery, the program under American Cancer Society has been functioning for five years. 2 ? She herself has been active as a volunteer for 15 years when she was requested by her own. surgeon to visit other women who had had mastectomies or were about to have the operation. She-described to me how the program operates in Oregon.

Voluntelers must be women who have had mastectomies themselves. Originally, there was" a requirement that they have had their

25 Ibid, 12

26 Ibid, 158

27 Personal interview with Mrs. Nora Janik, State Coozdinator Reach to Recovery, American Cancer Society, Oregon, February, 1975 
operation five years prior. However, because more volunteers are needed, this restriction was recentiy dropped to three years. The idea behind this requirement is to assure that the potential volunteer will have had the opportunity to resolve her own feelings regarding her operation. “. She also needs a letter from two physicians attesting to the lact that she is emotionaily and physically recovered.

She must then take a training program to help her in visiting mastectomy patients. This serves as a screening process as well for the few who would not be well suited for the program's activities. As Mrs. Janik states, the emphasis is on what not to say. Some of the "don'ts" are:

Never'compare surgeries.

Never talk about your own surgery.

Never 'use doctors' names.

Never use patient's' names.

Never answer questions that require a medical answer.

After the training, the "visitor" or volunteer contacts women in hospitals only at the patient's doctor's request. One of the purposes of the visit is to present to the patient a woman who has gone through the surgery, is alive and weli, active and attractive; on the theory that one picture is worth a thousand words. The volunteer; in addition to presenting this moraleboosting image demonstrates the exercises that are necessary to regain the use of the arm. A pamphlet showing the exercises 
is left with the patient. The visitor may also put the patient through these exercises, if the doctor so desires and give her a temporary prosthesis.

The visitor may offer emotional support as well. She tries to heIp the patient anticipate what to expect such as:

1. unexpected crying periods

2. strange physical feelings

3. discomfort and pain from the exercises

4. the "well meaning friend" who may have false information

5. worries about relation with husband

6. how and what to tell the children

After the initial visit, which the visitor tries to make in the hospital, she may make a follow-up visit and invite the woman to attend Reach to Recovery meetings. Mrs. Janik stressed the fact that the meetings provide rehabilitative services and are not merely a club. The visitor may also help the woman with advice on where to obtain a permanent prosthesis.

Emphasized throughout the program is the idea that no one is visited without being referred by the surgeon who performed the patient's mastectomy. Any medical questions are referred to him and no one is visited who doesn't desire to be. The visitor works in cooperation with and only with the approval of the at tending surgeon.

Presently, there are about 65 visitors in Oregon and there are 50 physicians in the state who refer their mastectony patients 
to Reach to Recovery, Mrs. Janik states. According to her, one of the problems now is getting enough volunteers. Some drop out after a time, some may have a recurrence of the disease or, develop other ailments. As more physicians become aware of and interested in the service, there is a greater need for more yolunteers. A fairly active recruitment effort is made in checking the tumor registries of the state for the rames of potential volunteers.

When asked why some physicians or surgeons performing mastectomies do not use the volunteers, Mrs: Janik said she thought it was because they don't know about it, don't see a necessity for it or preier not to have a lay person talk to their patients.

In reviewing the literature, the only negative comment I could find was that of Dr. John Healey who felt that the medical profession was relegating an important aspect of medical rehabilitative care to a non-professional and that there could be some unfortunate consequences from an over-zealous volunteer who may not understand the physician's limitations of the patient. 28 The American Cancer Society has provided some safeguards for this in having a medical advisor for each

28 John E. Healey, Jr., M.D., "Role of Rehabilitative Medecine in Care of Patient with Breast Cancer", Cancer, December, 1971, Vol. 28, p. 1666-71. . 
unit. Mrs. Janik reported that in the five years the program has operated in Oregon, they have never received a complaint about the volunteers' activities.

Other activities that are undertaken by Mrs. Janik as state coordinator for the program are addressing-nurses groups as to the needs of post-mastectomy patients and talking at ministerial conferences as well. In addition, she has worked to develop new resources for breast prostheses, and these can now be purchased in most department stores.

The Reach to Recovery program appears to be a very sophisticated one in which the stumbling blocks have been anticipated and the volunteer offers the kind of support she feels she is best suited for. She leaves all medical and/or deep-rooted psychological problems to the experts and operates as an adjunct to the medical dọctor, working under his aegis. 


\section{CHAPTER II}

\section{DESTGN OF THE STUDY}

\section{METHOD OF INQUIRY}

A four-page questionnaire of 59 , questions was designed. (See Appendix B) Included in the questionnaire were two openended questions allowing the volunteers to comment further on their feelings at the time of their operation and what might have been helpful to them then:

The questionnaire was given to the volunteers at one of their meetings in February; $1975^{\circ}$ with Krs." Janik's permission and after she had reviewed it and made a few suggestions. Seventeen of the 32 Portland volunteers were present at this meeting. The questionnaires were filled out by all 17 and returned at this time. Being present when the questionnaire was filled out was an advantage since any questions that came up regarding the form could be answered then.

At Mrs. Janik's suggestion, questionnaires were mailed from the American Cancer Society at their expense to the 15 volunteers who were not at the meeting. None of these questionnaires was returned.

In adition, Mrs. Janik was interviewed for a more in-depth response to her own feelings regarding her mastectomy. Mrs. Janik 
also supplied a great deal of information regarding the Reach to Recovery program and her own experience as a volunteer.

Mrs. Nancy Brice, American Canoer Society, was interviewed regarding the Reach to Recovery program and its association with the American Cancer Society. It was she who suggested seeing Mrs. Nora Janik for more information. 


\section{TARGET POPULATION}

The writer decided to use the 32 Reach to Recovery volunteers actively participating as "visitors" in the Portland area as a target population to whom a questionnaire could be addressed. The reason for using this. group was that they are women who have had mastectomies themselves as well as presently engaged in counseling other mastectomy patients. Approval for contacting the volunteers was given by Mrs. Nancy Brice, Service Director, American Cancer Society, Oregon Division, and. Hís. Nora Janik, State Coordinator Reach to Recovery, American Cancer Society, Oreg̣on Division. 


\section{QUESTIONNAIRE DESCRIPIION}

Questions $1-21$ related to the characteristics of the social, economic, educational and religious background of the volunteers.

Questions $22-49$ were questions relating to the volunteers' experiences and feelings at the time of their mastectomy. Questions $36,46,47$, and 48 related to the effect of the illness on their present life.

Questions 51-59. related to their experiences as a Reach to Recovery volunteer.

Question 56 concerned the issues covered in counseling. post-mastectomy patients. 
IV LIMITATIONS OF STUDY

A. Review of Literature

Although there was not a lot of material written on the subject in professional journals, what was written related directly to the psychological aspects of breast cancer and mastectomies.

It would have been helpful in updating the material to have had available the proceedings from the Third National Conference on Breast Cancer sponsored by the American Cancer Society held in Dallas in 1974. These had not been published at the time the study was undertaken.

\section{B. Target Population}

It would have been interesting to administer the same questionnaire to a group of post-mastertomy patients who were not Reach to Recovery volunteers to compare the responses of the two frolips and their characteristics. However, because the American Cancer Society protects the people who avail themselves of their services by maintaining a strict confidentiality regarding their names, there was no access to this population of post-mastectomy patients whom the volunteers see.

\section{Most Recent Mastectomy Three Years Ago}

In order to be accepted as a volunteer in the Reach to 
Recovery program, a period of three years must have passed since the potential volunteer's breast surgery.

For this reason, information regarding more recent experiences with counseling prior and post-surgery was not available. It would have been interesting to know if there has been greater emphasis on counseling mastectomy patients at the time of their operation in the last three years. 
RESULTS. OF THE QUESTIONNAIRE:

I QUESTIONNAIRE.

Questions I - 21 dealt with the general characteristics of the women who are volunteers in the Portland program and their social, educational and religious background. The results showed a remarkable homogeneity. The "profile" of the Portland Reach to Recovery volunteer is that of a woman, over 45 , married, with children in their late teens or older, who has attended college and probably has a degree either from a college or professional training school. She has lived in Portland over ten years and is most likely employed in a full or part-time job. Her family income is over $\$ 15,000$ a year, and she belongs to from one to three other community organizations in which she is moderately to actively involved. She considers herself a religious person and belongs to a church which she attends regularly.

Table I, following, shows in more detailed form some of the characteristics of the volunteers. 
- TABLE I

DATA FOR THE ANALYSIS OF CHARACTERISTICS OF VOLUNTEERS

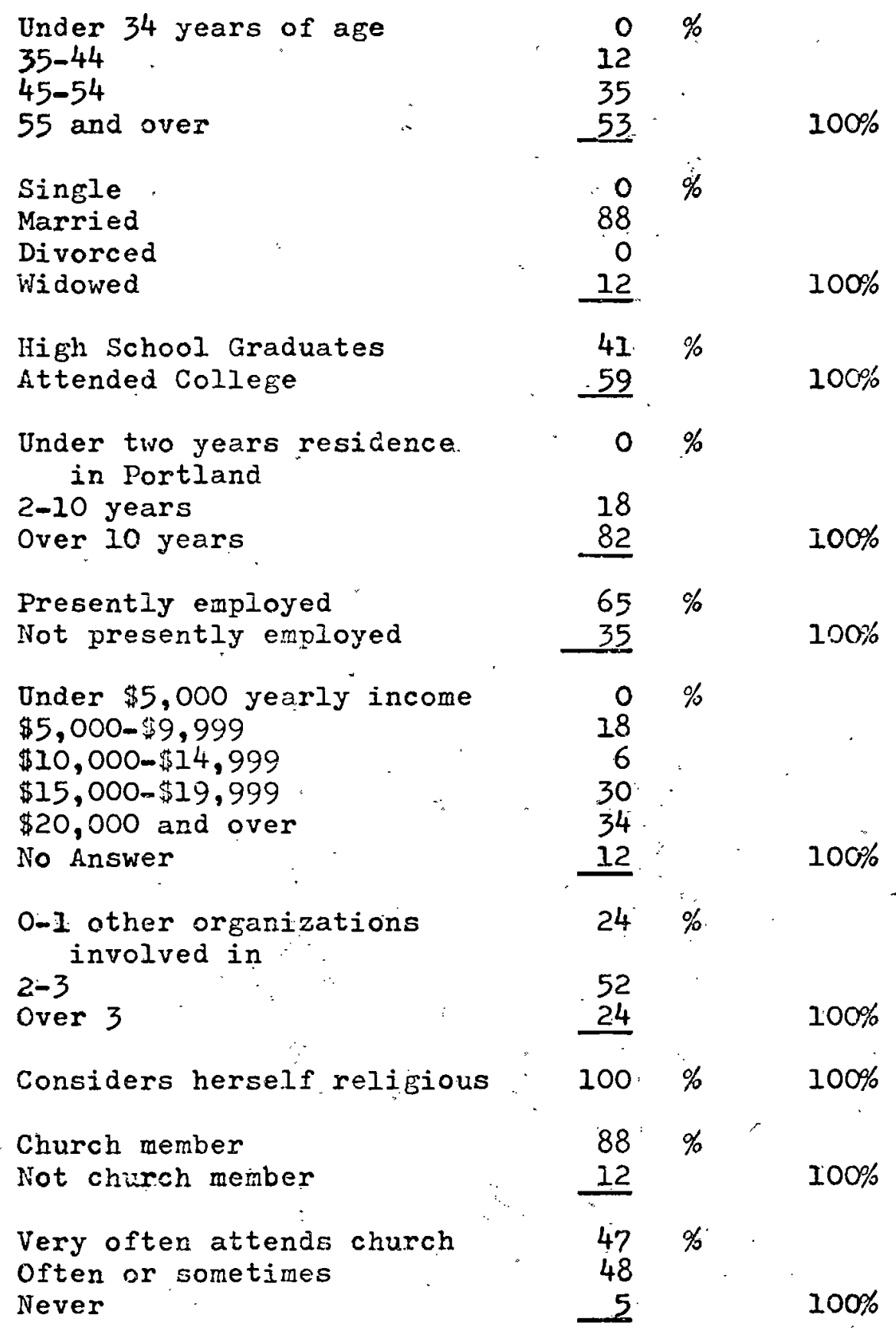


Questions 22 - 49 dealt with the volunteers' own ex-

periences regarding their mastectomies: The respondents

indicated as shown on Table II below the length of time it had been since their surgery.

It is important to note that the Reach to Recovery program will not accept women as volunteers who have had their mastectomy more recentiy than 3 years prior to entering the program.

Two of the women had had mastectomies at two different times.

TABLE II

PERCENTAGE OF VOJUNTEERS HAVING SURGERY EROM ZERO TO 20 YEARS $100 \%$

90

80

70

60

50

40

30

20

10

0

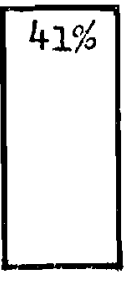

$0-5^{*}$ years

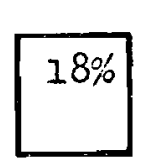

$6-10$ years

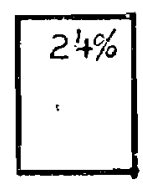

$11-15$ years

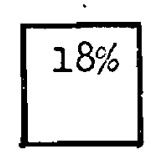

$16-20$ years

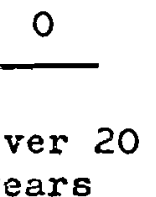

* None jess than three years.' 
Table III below shows how different people are seen as being helpfuI to the respondents both before and after their mastectomies. It is interesting to note that both before and after, the doctor and husband appear to be the most emotionaliy helpful people -- both male figures.

TABLE. III.

PERCENTAGE OF TIMES SIGNIFICANT PERSONS INDICATED AS BEING MOST HELPFUL EMOTIONALIY BEFORE

AND IMMEDIATELY AFTER MASTECTOMY

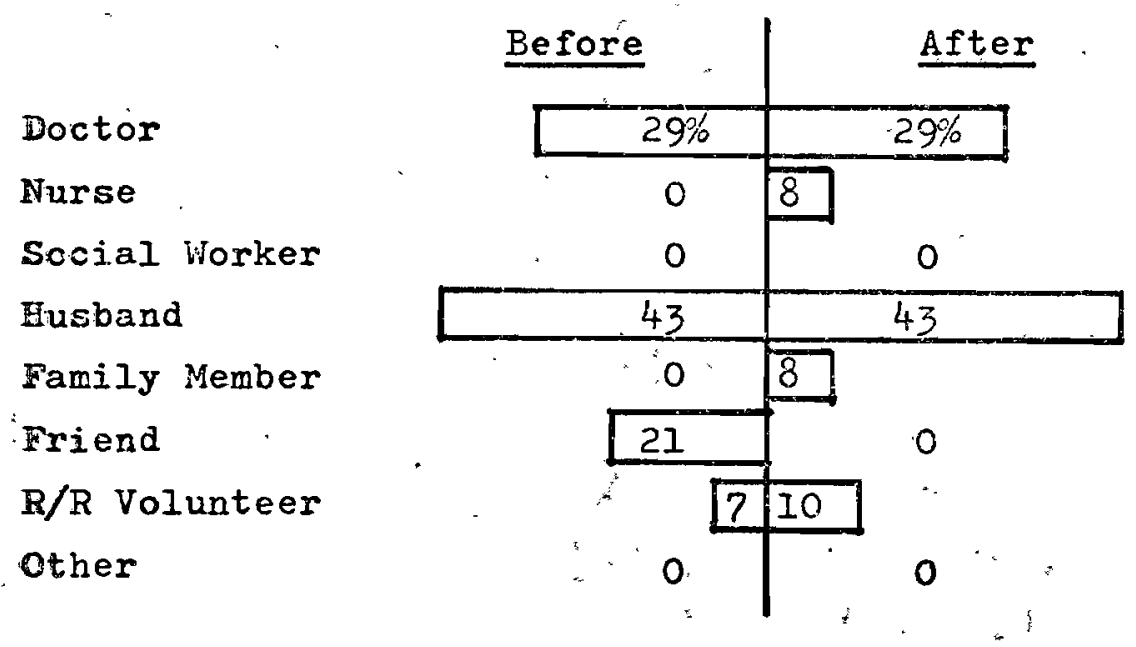

Only $18 \%$ of the respondents indicated that they had received prior counseling, whereas $53 \%$ indicated they had received post-operative counseling.

The following Table IV shows who the people were who did the counseling. Since most of the counseling was received after the operation, it is interesting to note that the nurse was most often the counselor.

Since the most recently that the operation could have been done was three years ago, it is important to remernber 
that social workers were not employed in most local hospitals then and the Reach to Recovery program in Oregon was only two years old.

\section{TABLE IV}

PERCENTAGE OF TIMES SIGNIFICANT PERSONS INDICATED

AS DOING COUNSELING BEFORE AND IMEDIATELY AFTER MASTECTOMY

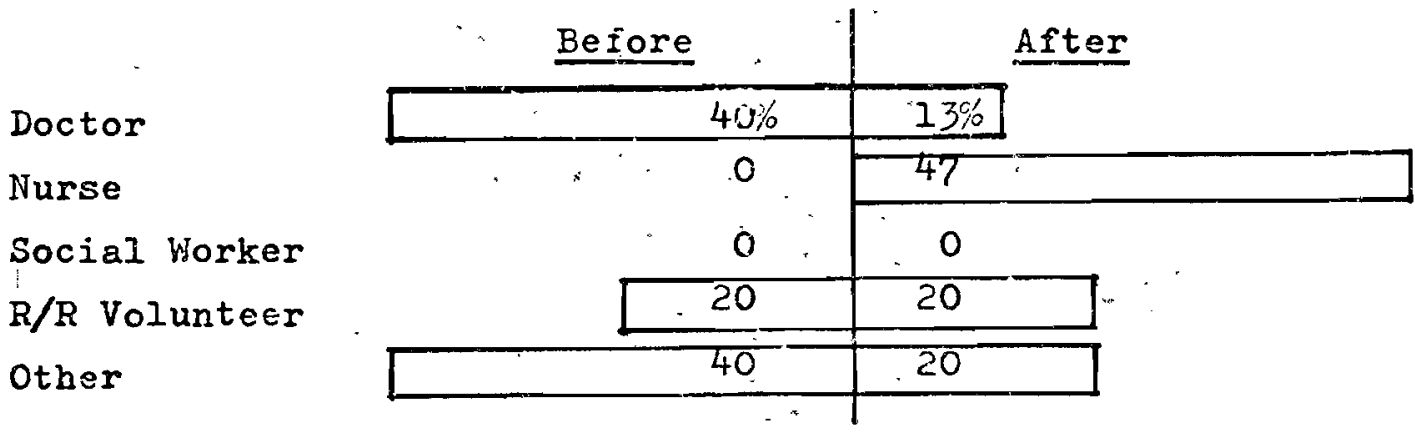

Questions 35 and 36 asked the respondents to indicate what issues were of Ereatest concern to them at the time of their operations and presertiy..

Table $V$ shows how the respondents rated the significance of the following concerns. It appears that fear of recurrence of disease was and is of greatest concern. 


\section{TABLE V}

DATA RELATING TO SOME ISSUES SURROUNDING BRELST CANCER AND MASTECTOMIES AND THEIR RELATIVE SIGNIFICANCE TO RESPONDENTS.

$\begin{array}{lcc} & \text { * At Time of } & \text { Presentiy } \\ \text { Fear of recurrence of } & 9 & 9 \\ \quad \text { disease } & 0 & 0 \\ \quad \begin{array}{l}\text { Fear of change in body } \\ \text { Equaliy fearful of both }\end{array} & 4 & 1 \\ \text { Not fearful of either } & 3 & 6\end{array}$

* Number of times indicated as significant by volunteers.

In answering whether they felt a need to talk about these fears to someone, $65 \%$ of the respondents said they did. Of those who answered "yes", $91 \%$ of them felt there was sorneone to whom they could turn.

$65 \%$ of the respondents indicated they had adjusted to their mastectomies "easily" -. 35\% "reasorably well" and $0 \%$ "with great difficulty".

In answering questions about how others had reacted to them after their operations, $94 \%$ said there had been no withdrawal from them on the part of their family members; $82 \%$ stated they felt no withdrawal on the part of those outside the family.

In discussing their family members' difficulties in 
accepting the diagnosis, $70 \%$ reported their husbands as having no difficulty; $53 \%$ reported their children as having no difficulty.

$88 \%$ of those questioned renorted their marriage relationship was either the same or better now than prior to their mastectomy.

65\% indicated that ife had changed for the better, since then; $29 \%$ reported it to be different but neither worse nor better and $0 \%$ reported it to be worse. ( $6 \%$ did not answer.)

Questions. 51 - 59 dealt with the respordents' experiences as a Reach to Recovery volunteer.

In answering the question regarding her motivation for joining Reach to Recovery, some of the following were indicated more than once by each volunteer, as shown on Table VI. .

The reason, "because I was not counseled and felt a need for it" was chosen almost twice" as often as any other category, and second to this was "another $R / R$ volunteer". 


\section{TABIE VI}

REASONS GIVEN FOF JOINING REACF TO RECOVERY

\# of Times Indicated By $R / R$ Volunteers

Another $R / R$ volunteer

5

Because I was helped myself by $R / R$

Because I was counseled myself and it was helpful

Because I was not counseled and

felt a need for it

My doctor encouraged me to volunteer

Other

The volunteers were asked to indicate whether the women they visited described their husband (or male friends) as being very sympathetic, or, in varying degrees to the opposite end of showing hostile feelings toward them after their operation.

There was an extremely high percentage of choices in the sympathetic, concerned and helpful range, and one only reported hearing of negative feelings. Three of the volunteers said they didn't know.

Table VII below related to the kind of subject matter discussed with the consultees by the $R / R$ volunteers. Each volunteer made more than one selection, showing which topics. she discussed. "Physical rehabjlitation" and. "Personal appearance" appear to take up much more time thrin the deeper issues of "Fear of "recurrence of disease" and "Fears regarding 
change in body image".

TABLE VII

TOPICS REIATING TO CONSULPEES MATECTONIES MOST FREQUENTIY DISCUSSED WITH THEM BY REACH

TO RECOVERY VOLUNTEERS

\# Of Times Indicated

By $R / P$ Volunteers

Physical rehabilitation

13

Personal appearance

12

Fears regarding recurrence

of disease

6

Fears regarding change in body image

Others

1

$52 \%$ of the volunteers indicated they made one visit to the patient; $25 \%$ made two and $23 \%$ made one to three visits.

$86 \%$ of the respondents said that their husbands supported.

their Reach to Recovery activities "very enthusiastically".

According to the table below, the highest percentage of volunteers has: been involved with the program from four to ". six, years.

\section{TABLE VIII}

LENGTH OF TIME VOLUNTEERS „HAVE SERVED. IN PROGRAM

Under one year

$12 \%$

One to three 35

Four to six

41.

Seven and over

12

$100 \%$

* Had done volunteer work before Reach to Recovery program started in Oregon. 
Two open-ended questions were included in the questionnaire. One of the guestions was in regard to the respondent's own feelings at the time of her operation and now.

Some of the responses were:

"the fear is ever present"

"I try to encourage myself that they got it all":

"I have a bright outlook on my condition"

"I think I keep my concern'minimized by being: involved with $\mathrm{R} / \mathrm{R}^{\text {" }}$

The second question asked the respondents to mention what was done or might have been done to make the time around their. operation an easier one.

Some answers were:

"accept the situation and be yourself"

"I was lucky to have been given an optimistic attitude by God, a wonderiul fanily, a loving circle of friends and a very deep faith in God's choice for me"

"would have likea a concentration on me and my needs"

"would have been easier if I had had a $R / R$ visitor" 
II INTERVIEN NITH MRS, NORA JANIK

Mrs. Janik, as state co-ordinator for Reach to Recovery has been involved with the program since its inception five jears ago, and, as mentioned previouṣly in the study, did volunteer counseling of mastectomy patients before then at her doctor's request.

Because of her long involvement in the program, it seemed important to gain a more "in-depth" approach to some of the issues raised by breast cancer and a mastectomy by. interviewing Mrs Janik.

In speaking of her own primary concerns; she said that fear of the recurrence of the disease was surely. a major concern, but that the saving aspects of the surgery were what she felt to be most important. She expressed the thought that she would like to see the positive aspects of cancer therapy emphasized more often. Because of surgery and therapy people are able to live longer lives.

Her own philosophy, as she described it, is that she wants something good to come out of her own experience with breast cancer and that helping others is" a way to bring a positive aspect to her ordeal.

Mrs. Janik feels that the emphasis on sexual concerns following a mastectomy is highly over-drawn. Her own experience was that she was glad to be alive and concerned about how well 
she could function -- when she could drive a car or use her arm, for example -- and return to a normal life.

Her emphasis in how to deal with others in her family after her operation is to do the same things and behave in the same way as before. She particularly stressed the importance of taking her husband into her confidence and honestly telling him of her feelings.

Mrs. Janik is a very attractive, well" groomed and well dressed, middle aged woman wino brings a great deal of energy to her endeavors, and this 'is irue oí the other volunteers I met as well. She must present a very reassuring and hopeful image to the mastectomy patients she visits. 


\section{CHAPTER IV}

CONCLUSIONS AND RECORMENDATIONS.

I BACKGROUND AND CHARACTERISTICS OF THE VOLUNTEER.

As mentioned earlier, the similarities among the volunteers are striking. It would be expected that the age group would cluster in the above 45 category since the peak ago group in breast cancer is 40 - 44 years of age.

The above $\$ 15,000$ income level, high educational achievement, strong religious involvement, as weil as the fact that none are single or divorced, and have long-standing community ties, sets these women well apart from the general population. One might speculate that their medical care would have been better than average and perhaps their counseling experiences at the time of their operation the best that could have been had. 
II COUNSELING EXPERIENCES AND PERSONAL FEELINGS

It is interesting that very îf received counseling before their mastectomy but more than half received some post-operative counseling. In the literature, it. was pointed out that it is well to start the counseling prior to the operation since the. woman is in a crisis state from the moment she knows she will have to have a breast biopsy.

Where counseling was done post-operatively, the nurse is the person most often mentioned as the counselor. In the litérature, a plan in operation at" Good Samaritan Hospital in Phoenix is described where a nurse is assigned to a woman when she is admitted for a breast biopsy and remains with her until she is discharged. 29 . The nurse not only counsels and supports the patient but takes back to the medical team information that will be helpful in planning for her hospital care and discharge.

It was interesting that in responding to the questions of who seemed most supportive to then before and after the operation, the respondents mentioned husbands first and their dector second. Although it is the nurse who is most often

29 Margaret Owen, "Special Care for Patient who has Breast Biopsy", Nursing Cinics of North America, June, 1972, Vol. ?, p. 373-82. 
charged with the counseling, she was mentioned oaly by one respondent as being a significantly supportive and emotionally helpful person.

This may indicate a need for greater consultation services in mental health concepts and specifically the emotional needs of post-mastectomy patients be made available to nurses. Such a service might be provided by the hospital social service staff and/or a Reach to Recovery representative.

It was interesting that the most sympathetic persons, as seen by the respondents, (husband and doctor) are both male figures. The first choice of "husband" may well reflect the marital status of the respondents and it may be that postmastectomy patients need and seek out the reassurance of a male figure who can make then feel "okay" about themselves as women. Social workers were not mentioned by any respondents as doing the counseling or as being significantly helpful or supportive. This is not surprising since so few Oregon hospitals used the services of social workers three years ago or earlier: It would be interesting "to"know if any hospitals now use their social service workers-for direct service to postmastectomy patients or consultation to medical personnel. Again, Reach to Recovery yolunteers were not mentioned as often as doctors or husbands, but the program was only two years old or not in existence at all at the-time the respondents. surgeries were performed. 
In speaking of their own feelings and concerns regarding the disease and operation at the time of their surgeries, the respondents most often stated that fear of recurrence of the disease was predominant and any concerns regarding body image were secondary. They also indicated they felt they had someone to turn to who would be a sympathetic listener and this was most often their husbands. It would be interesting to know if divorced or single women would choose a male figure as being a sympathetic listener or if they would feel they had someone to turn to at all.

In answering the question regarding their present fears, again, fear of disease recurrence was mentioned as often as previously, but the number expressing some fears of change in body image dropped and the numbers professing to be not fearful rose. This suggests that perhaps one must learn to live with the idea of recurrence of the disease, but that rears and concerns involving body image can be resolved. 


\section{COUNSELING SERVICES}

From the results of the questionnaire, it seemed that the post-mastectomy patients visited by Reach to Recovery volunteers overwhelmingly. viewed their husband and/or male friends as being sympathetic and concerned. This again supports the conclusion of the male figure being seen as very supportive and making patient feel good about herself.

It was particularly interesting to note that by far the greatest amount of time in the volunteer's counseling service is spent on physical rehabilitation and pexsonal appearance and very little time is spent relating to fear of recurrence of disease or change in body image. In light of the previous information that the volunteers themselves consider recurrence of the disease a primary concern, it is interesting that this matter doesn't come up more often in, their counseling.

This particular finding raises more questions than it answers. One might speculate that because the number of visits

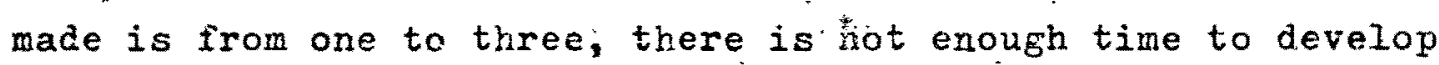
a. relationship that would encourage the discussion of such matters. Or, it could be that the volunteer does not feel comfortable in discussing an issue that is of such great concern to herself, and she needs to defend herself against these feelings. It might aiso be that since the possibility of recurrence of the disease is an ever-present reality, each 
person must come to terms with it in theix own way and learn to Iive with that fear.

In addressing itseif to the needs of physical rehabilitation and personal appearance, the Reach to Recovery program aims at reassuring and helping the patient regain her self-confidence and improve the quality of her life. Perhaps one can deal better with the deeper issue of a life-threatening disease if the time left is an enjoyable one. To summarize, it seems clear from both the literature. and the results of the questionnaire that there is a need for counseling mastectomy patients ana that within the past five year's the need has become recognized by both professional and lay people. It appears also, that although progress has been made in this area, more needs to be done. The Reach to Recovery volunteer program is a recognized and effective method of providing rehabilitative and emotional support to mastectomy patients. It would appear that the counseling provided by medical personnel, in most cases the nurse, needs improving in the way of better training, that more hospitals need counseling programs and that the counseling be made available to more patients. The most often given reason for joining Reach to Recovery was that the volunteer had not been counseled herself and felt the need for such counseling. 
IV. INDICATION FOR FURTHER STUDY

The areas where further' study is indicated are as

\section{follows:}

1. Update the current status of breast cancer patients by referring to the proceedings of the 1974 Breast Cancer Symposium, sponsored by the American Cancer Society in Dallas.

2. Extend the target population to a general group of post-mastectomy patients and those who have had the operation more recently than three years ago.

3. Survey counseling methods used in portland and/or Oregon hospitals and what staff is available for counseling.

4. Investigate poss ble job and insurance discrimination, which may be directed toward mastectomy victims. 
Akehurst, A. C., "Post-Mastectomy Morale", Lancet, July, 1972, Vol. 2, p. 181-2.

"After-Cancer Effort Funded", Oregon Journal, February 3, 1975, Portland Oregon, The Oregonian Publishing Co..

American Cancer Society. "173 Cancer Facts \& Figures", New York, 1973.

American Cancer Society. "Cancer Word Bool", New York.

Bayh, Marvella, "Betty, Happy and Me", Ladies Home Journal, January, 1975, Vol. 92, p. 63.

"Cancer Survival Gained Litt2e in 60"s", The Oregonian, February 20, 1975, Portland, Oregon, The Oregonian Publishing Company.

Ford, Betty, "I FeeI Like I've Been'Reborn", McCall's, February, I975, vol. 102:5, p: 98 .

Goldsmith, Harry S., M.D. et aI, "Role of the Surgeon in Rehabilitation of Breast Cancer Patient", Eancer, December, 1971, Vol. 28, p. 1672-1675.

Harrell, Helen C., "To Lose a Breast", American Journal of Nursing, April, 1972, Vol. 72, p. 676-77.

Healey, John E., Jr., M.D., "Role of Rehabilitative Medicine in Care of Patient with Breast Cancer", Cancer, December, 1971, Vol. 28, p. 1666-71.

Klein, Roberta, "A Crisis to Grow On", Cancer, December, 1971, Vol. 28 , p. 1659-65.

Lasser, Terese, A Message to Husbands from Terese Lasser. Âmerican Cancer Society, New York.

Lasser, Terese, Reach to Recovery, A Marual for Women tho Have Had Breast Surgery, Revised Edition, 1969, American Cancer Society, New York. 
Lasser, Terese, Suggestions for Visiting the Patient, American Cancer Society, INew York.

Lasser, Terese, What is Reach to Recovery?, American Cancer Society, New York.

Lasser, Terese and Clarke, William Kendall, 'Reach to Recovery', New York: Simon and Schuster, I972.."

Markel, William M., M.D., "The American Cancer Society's Program for the Rehabilitation of the Breast Cancer Patient", Cancer, December, 1971, Vol. 28, p. 1676-78.

Owen, Margaret, "Special "Care for Patient Who Has Breast Biopsy", Nursing Clinics of North America, June, 1972, Vol. 7, p. 373-82.

Stein, Justin J., M.D., "Hi-Risk Groups", Cancer INews, Spring/Summer, 1974, Vol. 28, \#1, p. 4.

Sawyer, David, "I Married a Mastectomee", Cancer News, Spring/ Summer, 1974, Vol. 28, ffl. . . 12-13.

Sawyers, John L., M.D., "Reach to Recovery -- A Post Mastectomy Rehabilitative Program", Journal Tennessee Medical Association, January, 1973, Vol. 66, p. 28-9. 


\title{
APPENDIX A
}

\section{DEFINITION OF TEPMS*}

\author{
Benign Tumor - An abnormal swelling or growth that is not \\ malignant or cancerous. \\ Biopsy - The removal of a minute section of body tissue \\ for microscopic examination for the diagnosis \\ or prognosis of disease (usually cancer). \\ Cancer \\ - A general term indicating a variety of malignant \\ tumors which originate in a single abnormal body \\ cell and multiply and spread wildly. In its \\ natural course, if unchecked, cancer couses death \\ by invading vital body organs. \\ Clinical - Pertaining to the study and treatment of disease \\ in human beings, as distinguished from laboratory \\ research. \\ Diagnosis - Recognition of the nature of a disease by its \\ signs, symptoms, course and laboratory findings. \\ Lymph Node - A small mass of lymphatic tissue, often bean- \\ shaped. \\ Lymphatic - Body tissues which are filled with lymph, a \\ Tissue \\ clear fluid which carries white blood cells, \\ nourishing substances and some of the body's \\ various disease-fighting materials. \\ Malignant - One that grows and spreads and threatens life; \\ Tumor \\ cancer. \\ Mastectomy - Surgical removal of a breast.
}

- Cancer Word Book, American Cancer Society, New York. 
Prognosis - Prediction of the course of a disease and the future prospects.

Therapy - The treatment of disease.

Tumor - A swelling or enlargement; an abnormal mass, either benign or malignant, with no useful body function. 
APPENDIX B

Mrs. Elaine Iowe 2740 Sil Talbot Rd. Portland 97201 227-3894

QUESTIONAARE FOR REACH TO RECOV ZRY VOLUNTECRS

1. $\operatorname{sex}$

Male _ Female

2. Age

Under $25^{\circ} \ldots 25-34$ 55 and over.

$35-44$

$45-54$ : 55 and ovar.

3. Marital Status Now Single iidowed other Married Divoreed

4. Please list the ages of your chiliren (if applicable)

5. Please circie highest year of schooling completed

6. What subject or subjects in school were you most interested in?

7. Did you attend a secretarial school or some other kind of training school?

8. If you graduated from college or training school what was it that you received your degree or training in?

9. Have you ever resided outside the state of Oregon?

10. Have you lived in Oregon Under 2 years over 10 years

2 to 10 years

11. Thave you lived in portand area Undor 2 years over 10 years

12. Are you presently or have recently been employed in a salaried occupation?

13. If yes to 12 , part time $\therefore$ full time

14. If yes to 12, what is your job title?

15. What is your husbarid's occupation? 
16. Please check below the category which comes closest to your total family income before taxes:

Uinder $\$ 5,000$

$310,000-34,999$

$\$ 5,000-\overline{\$ 9}, 99 \overline{9}$

$\$ 15,000-\$ 19,999$

$\$ 20,000$ and over

17. How many other community organizations are you involved in?

18, If so, if this involvenent. *very active moderately active

not very active

19. Wo you consider yourself a religious person? yes no

20. Do you belons to a church? yes _ iro

21. Do you attend church very often seldom never

often

sometimes

The following questions relate to your own experiences and feelings as a woman. who has had a masectomy.

22. Fow long has it been since your operation?

23. Shat was your maritai status at the time of your operation? single married divorced wi dowed. otiner

24. Was there any advice or counseling given to you to.. -prepare you psychologicully for the possibility of a mesectomy immediately prior to your operation? yes no

25. If yes to 24 , by whom was this given? (If more than one of the following, please number $1,2,3$ etc. in order to importance to youl doctor nurse social worler friend church person any other. family

26. If there was counseling done in the hospital, as far as you know was this part of a regular hospital progrom individual effort by medical personnel _ don't $\mathrm{know}$

27. If you could choose one person who was most helpful to you emotionally immediately prior to your operation when you knew there was a possibility of a masectomy, wes it the doctor personnel nurse social worker other medical friend husbana other family membor 
29. Immediately after your masectomy, did you receive any advice or counseling while in the bospital? yes __ no

30. If yes to 29 , by whom was this done? doctor social worker Reach to Recovery volunteer nurse other

31. Do you feel that the information regarding a masectomy given "you was adeque,te more than I wanted to know would liked to have had more information

32. "Was this information given prior to the operation after the operation both not at all

33. Nere you visited by a Reach to Recovory volunteer after your operation? yes no

34. If so was this visit very helpful ; helpful, but could have done without it moderately helpful.

35. If you can recall your feelings immediately after your masectomy would you say a fear of recurrence of the disease "Was predominant fear of change in body image was dominant __ equaliy fearful of both __ not fearful of either

36. At this time would you say jour feelings involve a fear of recurrence of disease equally fearful of both fear of change in body image not feaful of either

37. Are there any remarks you would like to add to questions 35 or 36 ?

38. At that time, did you fesl. a need to taik about these fears to comeone? yes no

39. If yes to 36, was there someone you could turn to as a sympathetic listener yes _ no

40. If yes to 37, although more than one person may have becn helpful to a degree, who was rost helpiul in this pparticular way? doctor family member nurse social worker any other Reach to Recovery volunteer husband

41. In looling back, would you say you adjurtsd to your - masectomy easily "difficulty reasonably well with great 
42. After your operation, did you feel that some of your family members drew away from you?

Very much so __ Sonewhat __ SIightly

Tot at all

43. Did you feel that some outside your family drew aray from you? very much so Somewhat SIiEhtly Not at all

44. Vias it diacult for your husband to accept your diagnosis and operetion? very not at all

45. Tas it difficult for your children to accept your diagnosis and operation? vory somewhat not very not at all

46. Like any stressful event, a masectomy may put a strain on a marital relationship or with members of the opposite sex, if unmarried. Since your operation, would you say that your relationship with your husband (or male friends, if unmarried) has become stronger about the same not as strong

47. If you are now divorced, or have been divorced, would you say that your operation played a role that was very significant modorately sinificant not significant at all slightly significant not sicinicicant at all

48. Since your operation, do you feel that your life has changed for the better for the worse different but neither worse nor better

49. Are there any comments you would like to make about what could have or was done that made this an easier time for you and your family

51. Approximately how long have you been a Reach to Recovery volunteer?

52. Could you rank the following in order of their importance in your decision to volunteer your services in the Reach to Recovery program. Another $\mathrm{R} / \mathrm{Il}$ volunteer because I was helped myself by $\mathrm{R} / \mathrm{R}$ because $I$ was counseled at the time of my operation and it was helpful to me because I was not counseled at the time of my operation and I felt a need for j.t my doctor encouraged me to volunteer other 
53. What proportion of those womer whom you visit indicate that your visit was important to their recovery? a great many almost all about half some very few

54. Approximately how many women have you visjted who are welfare recipients?

55. Among the women you see how would you describe the attitudes of the husband or male friend toward the woman? very sympiathetic feeling uninformed feeling left out concerned helpful indifferent wegative feelings don't know (if more than one of above applies, mark more than one)

56. Could you indicate what proportion of your time with your consultees you spend, in general, on the following: physical rehabilitation matters regarding personal appearance fears re $\overline{\text { saraing }}$ recurrence of disease fears regarding change in body inage others

57. How often do women you see express satisfaction with the kind of enotional support they were given by medical personnel at the time of their operation? Very ofter _ sometimes occasionally seldom never

58. On the average, how many visits do you personally make to each women?

59. Hy husband has encouraged my lieach to Recovery activities very enthusiastically moderately not particularly not at ali 